\title{
Homeowner Best Management Practices for the Home Lawn ${ }^{1}$
}

Laurie E. Trenholm ${ }^{2}$

Everyone enjoys the look of a nice, healthy lawn in a landscape. Not only do lawns increase the value of property, they help to cool the environment and reduce soil erosion. Most importantly, a healthy lawn reduces pollution resulting from stormwater runoff, because it is able to actively filter and trap sediment or pollutants that might contaminate ground or surface waters. It is very important that homeowners follow best management practices when maintaining their lawns so as to not cause pollution to Florida's water resources. For a happy, healthy, and environmentally friendly lawn, follow the tips outlined below.

\section{Lawns Get Hungry}

All lawns will benefit from regular fertilizer applications throughout the growing season.

Applying the proper amount of fertilizer for your grass species will help to promote a vigorous, healthy lawn that can out-compete weeds and serve as a filter to protect Florida's ground and surface waters.

Homeowners should look for fertilizer products with slow-release sources of nitrogen, as these will be less likely to contaminate ground or surface waters and will provide longer residual response to the nitrogen.
You may apply up to $1 \mathrm{lb}$. of slow-release nitrogen per 1,000 square feet of lawn at any one time. If using a quick-release nitrogen source, do not apply more than $1 / 2 \mathrm{lb}$. of nitrogen per 1,000 square feet at one time. See Table 1 for the recommended fertilizer rates for your grass species and location in the state, and Table 2 for how to apply the proper nitrogen rates from the various fertilizer sources.

In south Florida, you can apply fertilizer approximately every 60 days throughout the year, but in north and central Florida, wait until danger of frost has passed before you apply fertilizer in the spring. Look for a fertilizer with a low phosphorus level (the second number on the bag) and a high potassium level (the third number on the bag) such as a 15-2-15 or something similar. It is important to test your soil to determine phosphorus levels. Florida soils are often high in phosphorus, so the addition of phosphorus may not be necessary and may result in phosphate pollution. Check with your local county extension office for information on how to submit samples for phosphorus testing.

If you have a small strip of lawn that adjoins impervious surfaces, use a drop-spreader that drops

1. This document is Fact Sheet ENH979, one of a series of the Environmental Horticulture department, Institute of Food and Agricultural Sciences, University of Florida. Publication date: April 2004. Please visit the EDIS website at http://edis.ifas.ufl.edu

2. Laurie E. Trenholm, Assistant Professor, Extension Turfgrass Specialist, Environmental Horticulture department, Institute of Food and Agricultural Sciences, University of Florida, Gainesville, FL 32611.

The Institute of Food and Agricultural Sciences (IFAS) is an Equal Employment Opportunity - Affirmative Action Employer authorized to provide research, educational information and other services only to individuals and institutions that function without regard to race, creed, color, religion, age, disability, sex, sexual orientation, marital status, national origin, political opinions or affiliations. For information on obtaining other extension publications, contact your county Cooperative Extension Service office. Florida Cooperative Extension Service / Institute of Food and Agricultural Sciences / University of Florida / Larry R. Arrington, Interim Dean 
the granules straight down rather than a rotary speader that would spread the particles in a $360^{\circ}$ circle. You may also carefully spread fertilizer by hand in these areas. If you are adjacent to water, leave a 10-foot strip around the water body unfertilized to avoid pollution.

If you spill fertilizer on the driveway or sidewalk, be sure to sweep it up and put it back in the bag. If fertilizer is not swept up, it will easily find its way down the storm drain and into the water supply. If fertilizer is spilled on the lawn, do not irrigate it into the lawn, but be sure to sweep up here as well. Store your unused fertilizer where it will stay dry and do not store it next to pesticides, fuel, or solvents.

\section{Let the Mowing Begin!}

Mowing may seem like the bane of your existence through the summer months, but it is actually one of the most important home lawn management practices. Follow these suggestions for a healthy, happy lawn:

- Never remove more than one third of the leaf blade at any one time. Removal of more than this can stress your lawn and leaves it susceptible to other problems.

- Mow at the highest height for your grass species. For St. Augustinegrass and bahiagrass, this is 3.5 to 4 inches. If you have St. Augustinegrass cultivars Delmar or Seville, mow at 2 to 2.5 inches. Mow centipedegrass at 1 to 2 inches.

- Leave grass clippings on the ground - they do not contribute to thatch and actually return a small amount of fertility back to the lawn.

- Keep your mower blades sharp - dull blades tear the leaf blades, making them look bad and leaving the lawn susceptible to insect or disease invasion.

- Don't mow your lawn when it's wet - this is dangerous for you, tough on the mower, and bad for the grass.

- If you miss a weekly mowing, raise the mower height so you don't remove too much tissue.
Bring the height back down to the recommended level slowly.

\section{Irrigation or Irritation?}

More lawns are damaged due to improper irrigation practices than any other single cultural practice. Train your grass to be more drought tolerant by employing the following methods:

- Irrigate less frequently but for longer periods each time. This will help train your roots to grow deeper in the soil, which will make your lawn more drought tolerant. Grasses irrigated in this manner will have a better chance of surviving watering restrictions.

- Turn your automatic sprinkler system off. Irrigate your lawn as needed. It is ready for water when the leaf blades start to fold in half lengthwise or when footprints remain visible in the lawn long after being made. Irrigate when at least $30 \%$ of the lawn shows these signs unless rain is forecast in the next 24 hours.

- In most parts of Florida, irrigate to apply $1 / 2$ to $3 / 4$ inches of water when you do irrigate. To determine how long you need to run your irrigation to achieve this, place straight-sided cans around the perimeter of the irrigation and see how long it takes to reach this amount. If you are in a very sandy soil, you want to apply the higher amount of water. Heavier clay soils can handle the 1/2-inch rate. In southeast Florida and the Keys, where soil depths are shallow, you may only need to irrigate $1 / 4$ inch to saturate the soil.

- Irrigate every two to three weeks during the winter months, even if your grass is dormant. The roots are still viable and this will help the grass green up more quickly in the spring.

- Irrigate around sunrise to fully allow leaf blades to dry out during the day.

\section{Weed Woes}

A lawn that is properly fertilized, mowed, and irrigated will typically out-compete most weeds. However, some degree of weed control is often 
required in spite of best cultural practices. Some

weeds can be chemically controlled after they have

emerged, while others, particularly grassy weeds, are harder to control when grown and are better controlled "pre-emergence." This requires the homeowner to know where the weed pressure is, to know what the weeds are, to select the right product for control, and to apply the product at the right time.

For pre-emergence crabgrass control, look for a product containing pendimethalin (available under multiple brand names). Apply this at label rates around the first of February in south Florida, mid-February in central Florida, and the first of March in north Florida. Whenever you apply chemicals, remember that the label is the law and that the directions must be followed!

For St. Augustinegrass lawns, atrazine is a commonly used herbicide for control of many broadleaf weeds. Be careful not to apply this when temperatures are high (greater than $85^{\circ}$ ), as it may injure the grass.

\section{In Conclusion}

The best defense against weeds or other lawn problems is to grow a happy, healthy, environmentally friendly lawn by following the fertilization, mowing, and irrigation tips as described above. Happy growing! 
Table 1. Recommended fertilizer rates for various home lawn grass species.

\begin{tabular}{|c|c|}
\hline Species/Location & $\begin{array}{l}\text { Interim N Recommendations } \\
\quad\left(\text { Ibs } 1000 \mathrm{ft}^{-2} \mathrm{yr}^{-1}\right)^{\star},{ }^{\star \star}\end{array}$ \\
\hline Bahiagrass - North & $2-3$ \\
\hline Bahiagrass - Central & $2-4$ \\
\hline Bahiagrass - South & $2-4$ \\
\hline Bermudagrass - North & $3-5$ \\
\hline Bermudagrass - Central & $4-6$ \\
\hline Bermudagrass - South & $5-7$ \\
\hline Centipedegrass - North & $1-2$ \\
\hline Centipedegrass - Central & $2-3$ \\
\hline Centipedegrass - South & $2-3$ \\
\hline St. Augustinegrass - North & $2-4$ \\
\hline St. Augustinegrass - Central & $2-5$ \\
\hline St. Augustinegrass - South & 4-6 \\
\hline Zoysiagrass - North & $3-5$ \\
\hline Zoysiagrass - Central & $3-6$ \\
\hline Zoysiagrass - South & 4-6 \\
\hline \multicolumn{2}{|c|}{$\begin{array}{l}\text { *Homeowner preferences for lawn quality and maintenance level will } \\
\text { vary, therefore we recommend a range of fertility rates for each grass } \\
\text { and location. Additionally, effects within a localized region (i.e., } \\
\text { micro-environmental influences such as shade, drought, soil conditions, } \\
\text { and irrigation) will necessitate that a range of fertility rates be used. }\end{array}$} \\
\hline \multicolumn{2}{|c|}{ ** These recommendations assume that grass clippings are recycled. } \\
\hline
\end{tabular}

Table 2. Examples of proper application rates for specific fertilizer products.

\begin{tabular}{|c|c|c|c|c|c|c|c|}
\hline Lawn & $6 \% \mathrm{~N}$ & $10 \% \mathrm{~N}$ & $12 \% \mathrm{~N}$ & $15 \% \mathrm{~N}$ & $16 \% \mathrm{~N}$ & $23 \% \mathrm{~N}$ & $27 \% \mathrm{~N}$ \\
\hline \multirow[t]{2}{*}{1000 square feet } & 8.4 pounds & 5.0 pounds & 4.2 pounds & $\begin{array}{l}3.3 \\
\text { pounds }\end{array}$ & 3.1 pounds & 2.2 pounds & 1.9 pounds \\
\hline & 17.4 cups & 9.5 cups & 8.7 cups & 7.25 cups & 6.5 cups & 5.5 cups & 4.75 cups \\
\hline \multirow[t]{2}{*}{1100 square feet } & 9.2 pounds & 5.5 pounds & 4.6 pounds & $\begin{array}{l}3.6 \\
\text { pounds }\end{array}$ & 3.4 pounds & 2.4 pounds & 2.1 pounds \\
\hline & 19.2 cups & 10.5 cups & 9.6 cups & 8.0 cups & 7.25 cups & 6.1 cups & 5.25 cups \\
\hline \multirow[t]{2}{*}{1200 square feet } & $\begin{array}{l}10.2 \\
\text { pounds }\end{array}$ & 6.0 pounds & 5.1 pounds & $\begin{array}{l}4.0 \\
\text { pounds }\end{array}$ & 3.7 pounds & 2.6 pounds & 2.3 pounds \\
\hline & 20.8 cups & 11.5 cups & 10.4 cups & 8.7 cups & 7.75 cups & 6.6 cups & 5.75 cups \\
\hline \multirow[t]{2}{*}{1300 square feet } & $\begin{array}{l}11.0 \\
\text { pounds }\end{array}$ & 6.5 pounds & 5.5 pounds & $\begin{array}{l}4.3 \\
\text { pounds }\end{array}$ & 4.0 pounds & 2.8 pounds & 2.5 pounds \\
\hline & 22.6 cups & 12.5 cups & 11.3 cups & 9.4 cups & 8.5 cups & 7.2 cups & 6.25 cups \\
\hline
\end{tabular}


Table 2. Examples of proper application rates for specific fertilizer products.

\begin{tabular}{|c|c|c|c|c|c|c|c|}
\hline Lawn & $6 \% \mathrm{~N}$ & $10 \% \mathrm{~N}$ & $12 \% \mathrm{~N}$ & $15 \% \mathrm{~N}$ & $16 \% \mathrm{~N}$ & $23 \% \mathrm{~N}$ & $27 \% N$ \\
\hline \multirow[t]{2}{*}{1400 square feet } & $\begin{array}{l}12.0 \\
\text { pounds }\end{array}$ & 7.0 pounds & 6.0 pounds & $\begin{array}{l}4.6 \\
\text { pounds }\end{array}$ & 4.5 pounds & 3.1 pounds & 2.7 pounds \\
\hline & 24.4 cups & 13.5 cups & 12.2 cups & 10.2 cups & 9.0 cups & 7.7 cups & 6.75 cups \\
\hline \multirow[t]{2}{*}{1500 square feet } & $\begin{array}{l}13.0 \\
\text { pounds }\end{array}$ & 7.5 pounds & 6.5 pounds & $\begin{array}{l}4.9 \\
\text { pounds }\end{array}$ & $\begin{array}{l}4.75 \\
\text { pounds }\end{array}$ & 3.3 pounds & 2.9 pounds \\
\hline & 26.2 cups & 14.25 cups & 13.1 cups & 10.9 cups & 9.75 cups & 8.3 cups & 7.25 cups \\
\hline \multirow[t]{2}{*}{2000 square feet } & $\begin{array}{l}16.8 \\
\text { pounds }\end{array}$ & $\begin{array}{l}10.0 \\
\text { pounds }\end{array}$ & 8.4 pounds & $\begin{array}{l}6.6 \\
\text { pounds }\end{array}$ & 6.2 pounds & 4.4 pounds & 3.8 pounds \\
\hline & 34.8 cups & 19.0 cups & 17.4 cups & 14.5 cups & 13.0 cups & 11.0 cups & 9.5 cups \\
\hline \multirow[t]{2}{*}{2500 square feet } & $\begin{array}{l}21.0 \\
\text { pounds }\end{array}$ & $\begin{array}{l}12.5 \\
\text { pounds }\end{array}$ & $\begin{array}{l}10.5 \\
\text { pounds }\end{array}$ & $\begin{array}{l}8.2 \\
\text { pounds }\end{array}$ & 7.8 pounds & 5.5 pounds & 4.8 pounds \\
\hline & 43.6 cups & 23.75 cups & 21.8 cups & 18.2 cups & 16.25 cups & 13.8 cups & 12.0 cups \\
\hline \multirow[t]{2}{*}{3000 square feet } & $\begin{array}{l}25.2 \\
\text { pounds }\end{array}$ & $\begin{array}{l}15.0 \\
\text { pounds }\end{array}$ & $\begin{array}{l}12.6 \\
\text { pounds }\end{array}$ & $\begin{array}{l}9.8 \\
\text { pounds }\end{array}$ & 9.4 pounds & 6.6 pounds & 5.8 pounds \\
\hline & 52.2 cups & 28.5 cups & 26.1 cups & 21.8 cups & 19.5 cups & 16.6 cups & 14.5 cups \\
\hline \multirow[t]{2}{*}{3500 square feet } & $\begin{array}{l}29.4 \\
\text { pounds }\end{array}$ & $\begin{array}{l}17.5 \\
\text { pounds }\end{array}$ & $\begin{array}{l}14.7 \\
\text { pounds }\end{array}$ & $\begin{array}{l}11.5 \\
\text { pounds }\end{array}$ & $\begin{array}{l}11.0 \\
\text { pounds }\end{array}$ & 7.7 pounds & 6.8 pounds \\
\hline & 61.0 cups & 33.25 cups & 30.5 cups & 25.4 cups & 22.75 cups & 19.3 cups & 17.0 cups \\
\hline \multirow[t]{2}{*}{4000 square feet } & $\begin{array}{l}33.6 \\
\text { pounds }\end{array}$ & $\begin{array}{l}20.0 \\
\text { pounds }\end{array}$ & $\begin{array}{l}16.8 \\
\text { pounds }\end{array}$ & $\begin{array}{l}13.2 \\
\text { pounds }\end{array}$ & $\begin{array}{l}12.6 \\
\text { pounds }\end{array}$ & 8.8 pounds & 7.8 pounds \\
\hline & 69.6 cups & 38.0 cups & 34.8 cups & 29.0 cups & 26.0 cups & 22.0 cups & 19.5 cups \\
\hline \multirow[t]{2}{*}{4500 square feet } & $\begin{array}{l}37.8 \\
\text { pounds }\end{array}$ & $\begin{array}{l}22.5 \\
\text { pounds }\end{array}$ & $\begin{array}{l}18.9 \\
\text { pounds }\end{array}$ & $\begin{array}{l}14.8 \\
\text { pounds }\end{array}$ & $\begin{array}{l}14.2 \\
\text { pounds }\end{array}$ & 9.9 pounds & 8.8 pounds \\
\hline & 78.4 cups & 42.75 cups & 39.2 cups & 32.7 cups & 29.25 cups & 24.8 cups & 22.0 cups \\
\hline \multirow[t]{2}{*}{5000 square feet } & $\begin{array}{l}42.0 \\
\text { pounds }\end{array}$ & $\begin{array}{l}25.0 \\
\text { pounds }\end{array}$ & $\begin{array}{l}21.0 \\
\text { pounds }\end{array}$ & $\begin{array}{l}16.4 \\
\text { pounds }\end{array}$ & $\begin{array}{l}15.8 \\
\text { pounds } \\
\end{array}$ & $\begin{array}{l}11.0 \\
\text { pounds }\end{array}$ & 9.8 pounds \\
\hline & 87.2 cups & 47.5 cups & 43.6 cups & 36.4 cups & 32.5 cups & 27.6 cups & 24.5 cups \\
\hline \multicolumn{8}{|c|}{$\begin{array}{l}\text { In this table, values given represent the percentage of } N \text { in the fertilizer bag, and the number of square feet of lawn area that you } \\
\text { have. Remember that } N \text { is the first of the three numbers on the fertilizer bag. The first value given is the weight of fertilizer to use for } \\
\text { the given lawn area in pounds. The second number tells how many cups of fertilizer this equals. }\end{array}$} \\
\hline \multicolumn{8}{|c|}{$\begin{array}{l}\text { The percentage corresponds to the first of the three numbers found on the bag. For example, use the } 15 \% \text { calculations when using } \\
\text { a } 15-2-15 \text { product. These figures assume that you are applying the recommended rate of } 1 / 2 \text { pound of nitrogen per } 1,000 \text { square } \\
\text { feet. For more information on lawn fertilization, please refer to the Residential Landscape section of http://turf.ufl.edu or consult your } \\
\text { local county extension service office for lawn fertilization fact sheets. }\end{array}$} \\
\hline
\end{tabular}

